\title{
ARKEOLOGI PULAU KOBROR KEPULAUAN ARU
}

\author{
The Archaeology of Kobror Island Aru Islands
}

\author{
Marlon Ririmasse \\ Balai Arkeologi Ambon \\ Jl. Namalatu-Latuhalat 97118 \\ ririmasse@yahoo.com
}

Naskah diterima: 21-06-2013; direvisi: 04-08-2013; disetujui: 06-09-2013

\begin{abstract}
The Aru islands is one of the key regions in the cultural historical study of Southeast Asia and Australia. This major role is represented at least by two aspects: firstly, the paleogeographical character of the Aru Islands as an extension of Sahulland that included New Guinea and Australia and secondly the role as a resource regio for exotic commodities such as pearl and bird of paradise. With this specific profile, Aru islands is potential to be studied archaeologically. Few archaeological studies had been initiated over last decade but still not balance with the colossal profile of regoin's cultural history. This study tries to contribute in improving such condition by focusing on the archeological potential in the kobror island. As an initial study, this research has adopted the reconnaissance survey as a key method to collect data. Referential study also has been adapted to reconigze the historical background of the region. This study found that two major aspects : firstly, the prehistotic character of the archaeological profile of the region as represented by the presence of a rock art sites and secondly, living tradition as reflected by the representation of cave burial that associated with the application of boat as a symbol and traditional religion.
\end{abstract}

Keywords: Archaeology, Kobror Island, Rock Art

\begin{abstract}
Abstrak
Kepulauan Aru adalah salah satu kawasan terpenting dalam studi sejarah budaya di Asia Tenggara dan Australia. Peran penting ini setidaknya diwakili oleh dua aspek: pertama, karakter paleogeografi Kepulauan Aru yang merupakan bagian dari perluasan daratan besar Sahul yang mencakup juga Papua dan Australia serta kedua, peran khas wilayah ini sebagai salah satu kawasan sumber komoditi eksotik seperti mutiara dan bulu burung cendrawasih. Dengan profil yang sedemikian kepulauan ini sejatinya memiliki potensi arkeologis yang cukup raya untuk dikaji. Beberapa penelitian arkeologis pada tahap mula memang telah dilaksanakan. Namun dirasa belum berbanding lurus dengan luasnya cakupan sejarah budaya wilayah ini. Tulisan ini mencoba untuk mengisi ruang dimaksud dengan memberi perhatian pada tinjauan atas potensi arkeologis yang ada di Pulau Kobror Kepulauan Aru. Sebagai sebuah kajian yang bersifat inisiasi, pendekatan yang digunakan adalah survei penjajakan guna merekam segenap data arkeologis yang ada di wilayah Kobror. Kajian pustaka juga dilakukan untuk menemukan kerangka historis wilayah kajian. Hasil penelitian menemukan aspek penting dalam tinjauan sejarah budaya di Kepulauan Aru: pertama adalah jejak budaya prasejarah yang teramati lewat situs lukisan cadas dan kedua, ragam tradisi berlanjut sebagaimana terekam dalam situs penguburan kuno yang tekait dengan aplikasi perahu sebagai simbol dan religi tradisional.
\end{abstract}

Kata Kunci: Arkeologi, Pulau Kobror, Seni Cadas 


\section{PENDAHULUAN}

Dua ratus lima puluh ribu rupiah adalah harga yang ditawarkan oleh penduduk untuk mendapatkan satu ekor bayi burung Kakatua berjambul kuning langsung dari tangan pertama. Menurut penduduk harga tersebut tergolong murah, karena di Dobo, lbu Kota Kabupaten Kepulauan Aru, harga ini bisa melonjak hingga limapuluh persen. D Ambon, ibukota Propinsi Maluku, harganya bisa mencapai lebih dari lima ratus ribu rupiah. Itupun dengan catatan bahwa burung ini bisa selamat dibawa melalui perjalanan jauh dan lolos berbagai pemeriksaan lintas pelabuhan.

Burung Kakatua (suku cacatuidae) memang sudah ditetapkan menjadi salah satu hewan dilindungi. Meski demikian kebutuhan ekonomi membuat burung ini tetap menjadi spesies yang diburu dan diperdagangkan ole penduduk di beberapa desa di Pulau kobror Kepulauan Aru. Biasanya burung ini diburu dengan cara dipungut dari sarangnya di atas pohon saat masih bayi, untuk kemudia dipelihara beberapa waktu sebelum dijua kepada pembeli. Penduduk di desa-desa Pulau Kobror biasanya menjual hewan ini ke Kota Kecamatan Benjina atau langsung ke Ibu Kota Kabupaten Kepulauan Aru yang terletak di Dobo. Perjalanan dari Benjina ke Dobo dapat ditempuh kurang lebih empat jam perjalanan lewat laut. Profil fisik Kakatua yang indah dengan perilaku yang lincah membuat hewan cerdas ini sejak lama dicari sebagai binatang peliharaan manusia. Disayangkan, aktifitas perburuan dan penyelundupan hewan khas ini, membuat populasinya semakin menurun.

Perdagangan gelap burung Kakatua memang merupakan salah satu gambara perdagangan komoditi khas di Kepulauan Aru yang telah berlangsung berabad-abad. Selain kakatua, Cendrawasih (Paradisaea Apoda) juga menjadi spesies burung yang paling dicari di kawasan ini sebagai komoditi dagang sejak masa lalu (Swadling, 1996) Keindahan dan keanggunan bulu burung cendrawasih membuat hewan ini menjad komoditi unggulan yang diekspor keluar dari
Kepulauan Aru. Jenis burung ini biasanya diawetkan sebelum dijual kepada pembeli. Saat ini cukup sukar untuk menemukan komoditi mahal ini, Burung Cendrawasih juga telah ditetapkan sebagai satwa langka yang dilindungi. Memperjualbelikan spesies ini adalah tindakan kriminal. Kenyataannya selama berada di Kepulauan Aru, beberap individu sempat menawarkan jasad burung Cendrawasih yang sudah diawetkan untuk dijual.

Aru memang lekat dengan perdagangan komoditi eksotik yang langka dan mahal. Saa ini, kepulauan Aru juga dikenal sebagai sentra produksi mutiara laut yang dikonsumsi pasar dunia. Demikian halnya dengan beberapa produk laut unggulan seperti Teripang dan Telur Ikan Terbang juga diekspor dar Kepulauan ini. Bukan kebetulan kiranya bahwa rekam sejarah menunjukan jenisjenis komoditi yang disebut di atas telah diperdagangkan di wilayah ini, bahkan hingga awal masehi (Ririmasse, 2010a Andaya, 1993a; 1993b). Suatu kenyataan yang mengagumkan, bahwa setelah lebih dari dua ribu tahun, semua yang disebut tadi tetap menjadi komoditi unggulan Kepulauan Aru.

Sejarah Budaya Kepulauan Aru memang sukar untuk dilepaskan dari dunia luar Hakekat sebagai wilayah sumber komoditi eksotik, membuat kepulauan ini senantiasa dicari oleh para pendatang dan pedagang asing. Studi terkait pengetahuan alam menunjukan betapa Kepulauan Aru memiliki sejarah yang lebih panjang. Meski kin menjadi bagian dari Kepulauan Maluku, Aru sejatinya merupakan bagian dari perluasan daratan besar yang disebut sebagai Paparan Sahul yang mencakup Papua dan Australia sebagai daratan induk. Himpunan wilayah in menyatu sebagai daratan besar pada jaman es. Ketika itu air laut surut hingga lebih dar 150 meter di bawah permukaan laut saat ini. Itulah sebabnya mengapa profil ekologi Aru menunjukan karakter yang mirip dengan wilayah tetangganya di timur (Ririmasse, 2010a; Spriggs et.al, 1998; O'Connor, 2005; Belwood, 1997). Di kepulauan ini kita bisa menemukan Burung Cendrawasih, sebagaimana umum ditemukan di Papua danidentik dengan Kangguru sebagai hewan endemik Australia. Perubahan muka laut yang menaik sejak akhir jaman es, membuat Aru menjadi kepulauan yang terpisah dari benua Induknya. Kondisi masa lalu inilah yang menciptakan karakter Kepulauan Aru sebagai sebuah wilayah dengan lingkungan dan sejarah budaya yang khas selalu menarik perhatian para penggiat ilmu pengetahuan dari berbagai bidang,termasuk Arkeologi.

Bukan kali pertama Balai Arkeologi Ambon melakukan studi di wilayah ini. Setidaknya dua penelitian oleh Balai Arkeologi Ambon sebelumnya dengan perhatian pada wilayah di pulau Wamar dan Wokam. Tinjauan atas pulau-pulau lain di Kepulauan Aru belum pernah dilakukan. Isu yang menjadi titik berat kajian kali itu juga terkait dengan tema-tema jejak budaya kolonial. Isu spesifik yang mencoba mengamati jejak budaya yang lebih awal, seperti ranah prasejarah belum pernah dilakukan. Bercermin pada kondisi inilah, Balai Arkeologi Ambon kemudian memutuskan untuk melakukan studi arkeologi lanjutan di Kepulauan Aru,kali ini dengan perhatian pada wilayah pulau Kobror yang terletak di sebelah tenggara Dobo.

Mengkaji sejarah budaya Kepulauan Aru berarti menggali kembali pengetahuan masa lalu yang dalam dan luas dari sebuah wilayah khas. Kepulauan ini memiliki dimensi waktu yang menerobos hingga awal kedatangan manusia serta kompleksitas dinamika wilayah ini karena kehadiran mereka. Keberadaan Aru yang senantiasa melekat dengan kawasan sekitarnya dan dunia luar.

Sejarah alam memahami keberadaan Aru sebagai satu kesatuan dengan Australia dan Papua; serta kontak dengan dunia luas dalam konteks dagang sebagai kawasan sumber komoditi eksotik adalah dua hal yang menggarisbawahi luasnya dimensi sejarah Kepulauan ini. Suatu kondisi yang menjadi cermin, bahwa upaya untuk memahami Kepulauan Aru dengan segenap kompleksitas sejarah budayanya membutuhkan waktu dan ersebut, perhatian studi arkeologi di Aru ali ini dititikberatkan pada Pulau Kobror di sebelah tenggara Dobo dengan masalah pokok yaitu:

1. Bagaimanakah profil potensi arkeologis yang terdapat dalam lingkup pulau Kobror Kepulauan Aru?, dan

2. Apakah indikasi jejak budaya prasejarah atau karakter budaya khas tersebut menunjukan keberlanjutan budaya prasejarah sebagai tradisi?

Sejalan dengan apa yang telah dipaparkan di atas, penelitian ini bertujua untuk mendapatkan gambaran profil potensi arkeologis di pulau Kobror, Kepulauan Aru. Secara khusus perhatian akan diberikan pada potensi arkeologis yang dipandang memiliki indikasi jejak budaya prasejarah termasuk karakter yang mencerminkan kontinuita budaya dalam tradisi masyarakat setempat.

\section{METODE}

Berkenaan dengan eksplorasi potensi arkeologis di wilayah ini, survei penjajakan dipilih sebagai pendekatan untuk menemukan data arkeologis. Dalam proses ini pengamatan atas potensi data di permukaan tanah akan menjadi prioritas untuk merekam situs-situs yang dipandang potensial guna kepentingan penelitian lebih lanjut. Selain deskripsi verba dan piktorial, rekam data juga dilakukan dengan foto dan pengukuran atas temuan dan situs yang dipandang perlu,serta rekam astronomis dengan GPS atas titik-titik situs.

\section{HASIL DAN PEMBAHASAN}

Kepulauan Aru: Tinjauan Wilayah Penelitian

a. Administrasi

Kepulauan Aru secara administratif merupakan Kabupaten yang menjadi bagian dari Propinsi Maluku. Terletak di bagian tenggara Maluku sehingga Aru merupakan 
gugus pulau paling timur dalam kepulauan Maluku.

\section{b. Geografi}

Secara geografis Kepulauan Aru berbatasan dengan Papua di sebelah utara da timur, Kepulauan Kei di sebelah barat dan laut Arafura di sebelah selatan. Keseluruhan terdapat sekitar 160 buah pulau yang membentuk kepulauan ini dengan luas lebih dari 8,563 km2 (O’Connor, 2005; Hidayat, 1998). Keletakan antara satu pulau dengan pulau lainnya sangat rapat dan membentuk total luas daratan mencapai $7050 \mathrm{~km} 2$. Satu pulau dengan pulau lainnya hanya dipisahkan oleh selat-selat sempit. Pulau terbesar adalah Wokam yang dikenal juga dengan sebutan Tanahbesar. Dobo, sebagai kota utama dalam wilayah terletak di pulau Wamar, yang berhadapan langsung dengan Wokam. Pulau-pulau utama lainnya adalah Kobror, Trangan, Koba, Kola, dan Maikor. Warilau adalah pulau paling utara, dan Enu adalah pulau paling selatan. Topografi Kepulauan Aru relatif datar dengan titik tertinggi $271 \mathrm{~m}$ di pulau Kobror. Di pulau-pulau besar lain titik tertinggi umumnya hanya mencapai 50-100 m.

c. Geologi

Profil geologis Aru menunjukan bahwa kepulauan ini merupakan bagian dari sat landas kontinen dengan Australia dan Papua. Wilayah-wilayah ini bahkan pernah terhubung secara langsung sebagai sebuah daratan besar pada Jaman Es, ketika air laut surut hingga 150 meter dari tinggi muka laut saat ini. Saa jaman es berakhir, menyusul meningkatny suhu bumi, Aru kemudian terpisah dan menjadi kepulauan yang mandiri. Kawasan di sekitar Kepulauan Aru hingga Selat Torres dan bagian utara lepas pantai Australia yang dulunya merupakan dataran rendah, menjelma menjadi kawasan laut dangkal. Relung-relung sempit antar perbukitan, berubah menjad selat yang di Aru umum disebut sebagai sungai meski dilalui oleh air laut (O'Connor, 2005; Spriggs et.al 1998; Spyer, 2000)

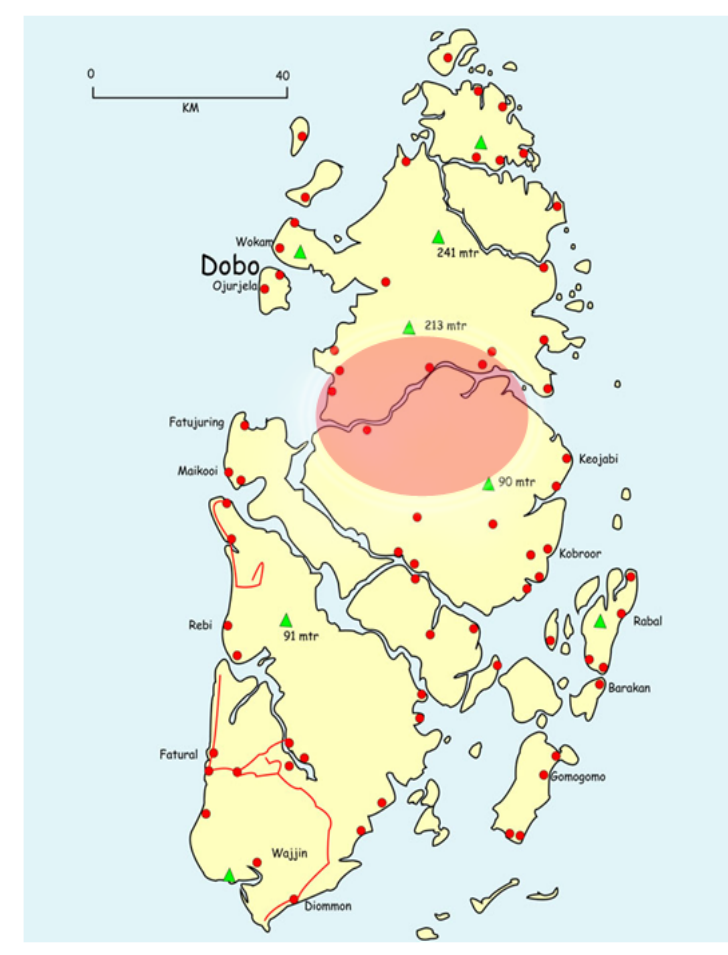

Gambar 1. Peta Lokasi Penelitian bertand lingkaran merah (Sumber: Wikipedia)

d. Flora

Dengan latar sejarah lingkungan yang sedemikian, karakter sebagai bagian dari Australia-Papua tetap teramati melalui profil ekologi Aru yang mirip dengan daratan induknya. Vegetasi di Kepulauan Aru dibentuk oleh formasi kombinasi hutan tropis yang lebat dengan hutan terbuka dan sabana. Setidaknya terdapat 2,000 spesies tanaman di wilayah ini. Tanaman dengan karakter batang yang menjulang hingga 40-60 m umumnya ditemui di pulau-pulau sebelah utara meliput Wokam, Kobror dan Koba. Jenis pohon tinggi yang dapat ditemukan adalah Pometia pinnata (Sapindaceae), Alstonia scholaris (Apocynaceae), and Syzygium (Myrtaceae) and Ficus species(Moraceae). Beberapa spesies lain yang penting dicatat oleh van Balgooy meliputi spesies Canarium spp., Flindersia amboinensis, Dillenia pteropoda, Instia bijuga (merbau), Maranthes corymbosa, dan Podocarpus spp. Jenis spesies tanaman di Aru memang tergolong kaya dan memiliki kemiripan morfologi dengan spesies-spesies yang terdapat $d$
Papua. Meski juga dapat ditemukan di beberapa tempat di Maluku, keragaman flora di Aru memang lebih raya dengan ciri yang cenderung serupa dengan Australia dan Papua. Pulau-pulau di sebelah selatan umumnya didominasi hutan terbuka dan sabana sebagaimana yang ditemukan di Pulau Trangan. Di hampir seluruh kawasan pesisir mudah ditemukan sebaran mangrove. Van Balgooy (1996) mencatat setidaknya terdapat tujuhbelas jenis mangrove di Kepulauan Aru mulai dari Rhizophora apiculata, R. stylosa, Ceriops tagal, and Bruguiera cylindrica. Avicennia officinalis, Sonneratiacaseolaris, Xylocarpus granatum hingga Camptostemon schultzii. Formasi sabana di Kepulauan Aru menunjukan karakter yang sama dengan kawasan serupa di Papua Bagian Selatan dan Australia Utara, khususnya di sekitar wilayah Cape York (O'Connor, 2005; van Balgooy, 1996).

e. Fauna

Situasi serupa juga ditemukan dalam profil fauna di Kepulauan Aru. Vertebrata kontemporer di wilayah ini cukup beragam dan didominasi hewan-hewan berciri Austrolo-Papua seperti marsupial, burung cendrawasih dan kasuari. Kondisi ini cukup kontras jika dibandingkan dengan kepulauan tetangga seperti Kei. Di wilayah ini jenis hewan tidak terlalu beragam dengan tipikal yang semakin berbeda dengan hewan Austrolo-Papua. Perbedaan ini menunjukan bahwa Aru memang merupakan bagian dari perluasan Papua dan Australia sepanjang Jaman Es. Jenis mamalia, burung dan reptil yang terdapat di Kepulauan Aru saat ini juga ditemukan di wilayah selatan Papua.

f. Penduduk

Saat ini penduduk Kepulauan Aru berjumlah 83.977 jiwa dengan presentase laki-laki sejumlah 43.565 dan perempuan sejumlah 40.412. Angka ini tersebar di lebih dari 120 desa dan kota Dobo. Hasil pengamatan selama di Aru menunjukan bahwa populasi terbesar terkonsentrasi di dan Benjina, sebuah kota kecil pelabuhan ikan di sisi barat pulau Kobror. Umumny para pendatang terkonsentrasi di dua kota ini.

\section{g. Ekonomi}

Ekonomi Kepulauan Aru saat in didominasi oleh usaha budidaya mutiara laut yang tentu saja dijalankan oleh para pemilik modal besar. Hasil budidaya komoditi maha ini biasanya ditujukan untuk pasar ekspor Perdagangan mutiara pada skala loka juga umum ditemukan, namun kualitasnya dibawah mutiara yang diekspor. Penduduk setempat juga banyak yang bekerja untuk perusahaan-perusahaan ini.

Meski saat ini penduduk lebih menempatkan beras sebagai pilihan substensi sagu masih menjadi alternatif utama di berbagai desa. Tanaman ini masih umum ditemukan dimana-mana dan dimanfaatkan oleh sebagian besar penduduk. Pisang, ubi dan jagung juga menjadi pilihan. Pengalaman selama tinggal di Kobror menunjukan sayuran cukup sukar ditemukan sehingga jarang dikonsumsi dengan berbagai variasi dalam menu sehari-hari. Bagi mereka yang menetap di kawasan pesisir terbuka (bukan sepanjang selat-selat kecil yang disebut sungai) melaut dan mencari ikan adalah sumber ekonomi utama (Healey, 1995). Perairan sekita Aru yang kaya sumber daya laut, membua wilayah ini juga menjadi sentra industri perikanan baik oleh kapal nasional pun asing. Benjina menjadi kota pelabuhan utama untuk penangkapan ikan. Pengolahan hasil hutan juga menjadi pilihan bagi ekonomi tradisional maupun korporasi. Beberapa perusahaan mendapatkan kosesi untuk melakukan penebangan kayu-kayu pilihan.

h. Sejarah

Data sejarah paling awal yang secara angsung menyebutkan mengenai Kepulaua Aru berasal dari naskah Suma Oriental oleh Tomme Pires dari tahun 1512-151 (Spyer, 2000; O'Connor, 2005). Catatan in kemungkinan berasal dari sumber sekunder 
selama Portugis berada di Malaka. Rekam resmi Portugis atas kawasan ini baru muncul pada tahun 1530 sebagaimana nampak peta pada masa itu. Meski Belan dari peta pas mongu benteng di Kepulaun in dan matidan sejak setidaknya abad ke-17, kehadiran da pengaruh Belanda baru benar-benar dirasaka semenjak abad ke-19. Beberapa jejak buday kolonial seperti sisa struktur benteng di Wokam masih dapat diamati hingga saat in i. Rekam Penelitian Arkeologi

Kontribusi terbesar terkait pengetahuan arkeologi di Kepulauan Aru disumbangkan oleh kompilasi penelitian bersama selama tiga musim antara tahun 1995-1997 oleh gabungan kelompok peneliti Indonesia dan Australia. Archaeology of Aru Islands terbi pada tahun 2005 dan memuat aspek-aspe jejak budaya di Kepulauan Aru dari aspek potensi hingoa kronologi dari sudut pandang arkeologi. Empat penelitian ini yaitu mencakup 1). Ihwal awa hunian pada masa Plestosen 2). Perubahan Ekonomi pada Masa Plestosen hingga Holosen 3). Peran wilayah ini dalam proses penyebaran pemukiman penutur Bahasa Austronesia dam kawasan 4). Bnteraksi antara penutur Bahasa Austronesia dan NonAustronesia 5). Peran wilayah ini dalam kaitan sebagai salah satu kawasan sumber komodit eksotik. Kontribusi terbesar dari penelitian ini agaknya disumbangkan oleh data kronologi yang mencapai angka setidaknya 26,000 tahun yang lalu. Pengetahuan lain yang penting disumbangkan oleh ragam informas terkait kondisi lingkungan masa lalu dan perubahannya terkait menaiknya muka laut pada akhir masa Plestosen.

Penelitian oleh Balai Arkeologi Ambon di wilayah ini telah dilakukan oleh Sudarmika bersama tim pada tahun 2009 dengan upaya untuk mengamati jejak budaya kolonial $\mathrm{d}$ Pulau Wokam. Penelitian kali ini secar spesifik diarahkan untuk melakukan eksplorasi terhadap wilayah selatan Kepulauan Aru, dengan perhatian pada Pulau Kobror.
Hasil Survei Arkeologis di Pulau Kobror Desa Sila Bata-Bata

Desa Sila Bata-Bata adalah salah satu desa utama dalam himpunan pemukiman yang terdapat sepanjang sungai Manumba yang memisahkan Pulau Wokam dengan Pulau Kobror. Dibanding desa lain, Sila Bata Bata memiliki populasi yang jauh lebih padat, pemukiman yang lebih luas dan yang terpenting, pelabuhan yang lebih ramai. Pelabuhan di desa ini agaknya menjadi titik transit bagi desa-desa di bagian pedalaman. Dari Benjina, kota kecamatan terdekat, desa ini dapat dicapai dengan perjalanan menggunakan motor laut dengan waktu tempuh sekitar 2 jam melalui sungai Manumbai. Survei yang dilakukan oleh tim penelitian dalam lingkungan desa, mendata keberadaan keramat desa, yang dipandang sebagai pusat kosmologi desa yaitu berupa rumah kecil dengan aneka piring putih sebagai sesajen. Objek ini terletak tepat setelah dermaga di pintu masuk desa Sila Bata Bata. Di samping struktur dikibarkan bendera putih. Komunikasi dengan kepala desa menyebutkan bahwa adalah umum bagi penduduk menyimpan aneka artefak kuna sebagai pusaka keluarga.

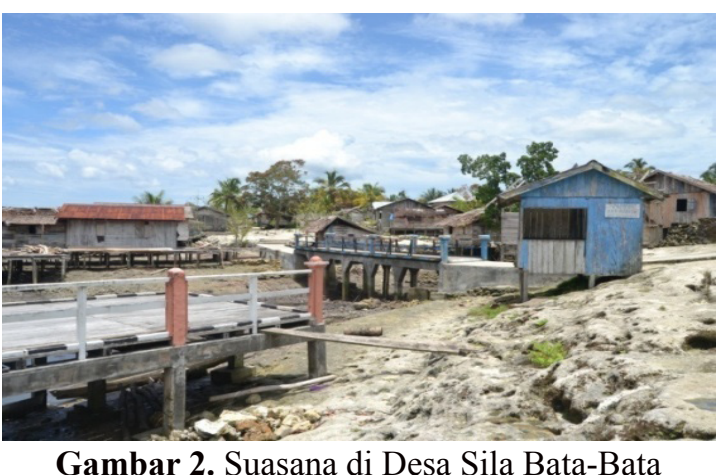

Gambar 2. Suasana di Desa Sila Bata-Bata (Sumber: Dokumen Balai Arkeologi Ambon)

- Penguburan Ceruk Terbuka di Sila Batabata

Situs penting dalam lingkup Sila BataBata adalah keberadaan situs Penguburan Ceruk yang terletak di kawasan seberang desa. Situs ini tepat berada pada ujung dinding formasi karst di bagian pulau Kobror. Untuk mencapainya kita harus menggunakan perahu dari Desa Sila Bata Bata sebelum melewati daerah bakau yang berlumpur.Pengamatan pada lingkungan situs menunjukan, ceruk rendah ini agaknya dibentuk oleh potongan aliran sungai. Saat pasang naik, ketinggian situs berada sekitar 2 meter dari permukaan sungai.

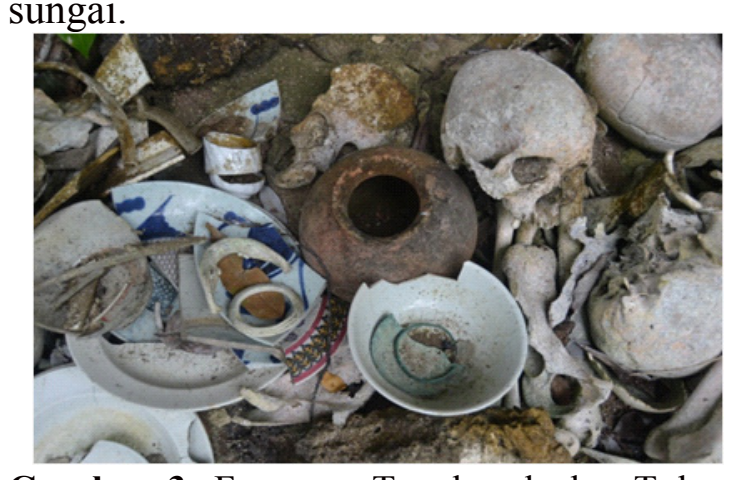

Gambar 3. Fragmen Tengkorak dan Tulang dalam asosiasi dengan gerabah lokal, keramik asing, gelang kerang dan fragmen logam (Sumber: Dokumen Balai Arkeologi Ambon)

Tepat di salah satu sisi sungai inilah terdapat teras yang melintang dari utara ke selatan. Di sinilah ditemukan situs penguburan terbuka. Tengkorak dan tulang beserta aneka bekal kubur tersebar di permukaan sepanjang teras ceruk. Melalui kalkukasi yang dilakukan, setidaknya terdapat lebih dari tigapuluh tengkorak. Selain tengkorak orang dewasa terlihat juga tengkorak anak-anak. Tengkorak dan tulang ini tersebar secara acak dan saling bercampur satu sama lain.

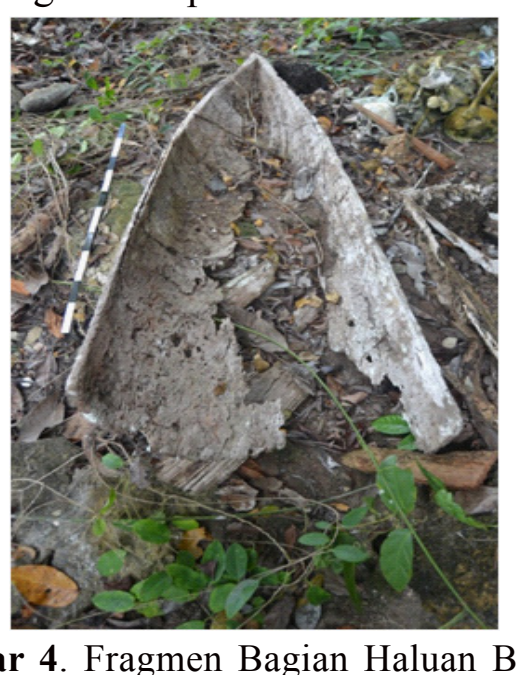

Gambar 4. Fragmen Bagian Haluan Bangkai Perahu Arwah

(Sumber: Dokumen Balai Arkeologi Ambon)
Jumlah besar temuan artefaktua yang agaknya merupakan bekal kubur umumnya didominasi oleh fragmen keramik cina, keramik voc, perunggu, piring, juga gerabah lokal. Temuan terpenting di situs in barangkali diwakili oleh keberadaan fragmen perahu yang digunakan sebagai wadah bag si mati. Saat tim melakukan pengamatan terdapat dua fragmen bangkai perahu yang agaknya merupakan satu kesatuan. Informasi penduduk menyebutkan dulu terdapat lebih banyak perahu arwah serupa sebagaimana yang ditemukan. Panjang fragmen pertama adalah $1,4 \mathrm{~m}$ dan panjang fragmen kedua adalah 1,2 $\mathrm{m}$. Lantai yang berbatu dengan lapisan sedimen yang tipis membuat situs in kurang potensial untuk dilakukan ekskavasi.

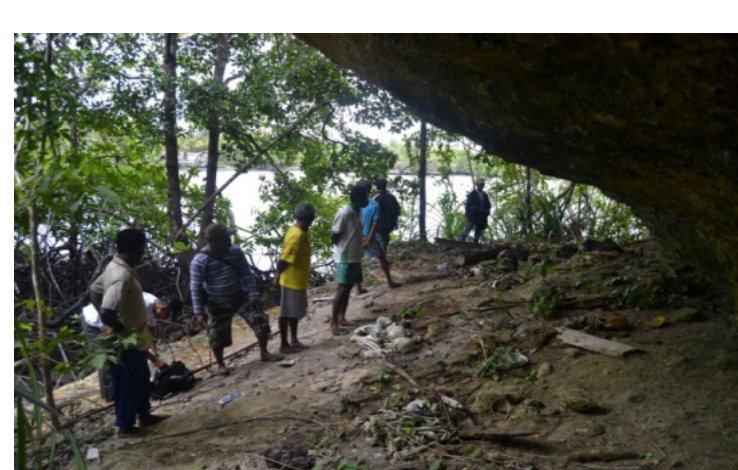

Gambar 5. Tim melakukan Survei di Situs Penguburan Terbuka di Ceruk Desa Sila Bata-Bata (Sumber: Dokumen Balai Arkeologi Ambon)

\section{- Gua Lisaibam:}

Lisaibam merupakan gua yang menjadi bagian dari wilayah (petuanan) desa Jirlay di pulau Kobror. Meski merupakan bagian dari desa, jarak tempuh menuju gua ini cukup jauh. Perjalanan menuju gua dapat dicapai dengan menempuh perjalanan menggunakan kapal motor melalui sungai Manumbai selama 1 jam dari desa Jirlay. Gua ini terletak sekitar 500 meter dari sungai terdekat. Untuk mencapainya harus melewati kawasan hutan bakau yang berawa.

Karakter fisik gua ini menunjukan bentuk terowongan tembus dari dua sisi Panjang gua mencapai 18,7 meter dengan lebar dan tinggi depan pintu 6,6 meter dan 1,9 meter; sementara pintu belakang memilik 
lebar 7,4 meter dan tinggi 2,4 meter. Arah hadap gua sendiri melintang dari timur ke barat dengan posisi 110 derajat untuk ke barat dengan posisi 110 derajat untuk Pencahayaan dalam gua cukup baik karena berasal dari dua pintu.

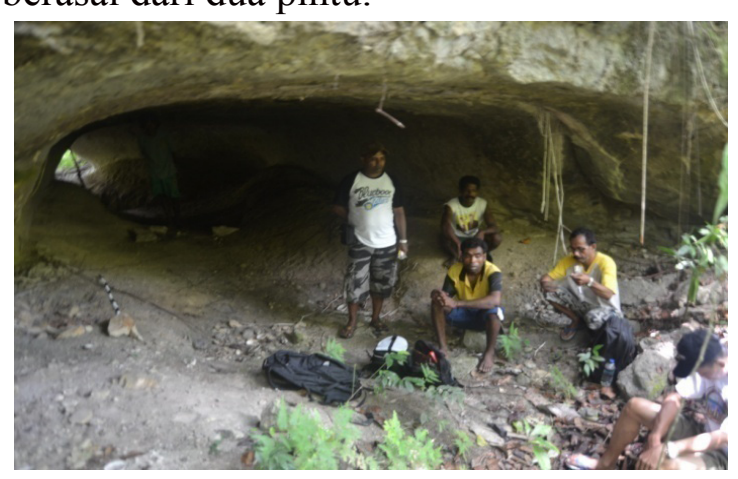

Gambar 6. Pintu Gua Lisa Ibam dari Sisi Uta

(Sumber: Dokumen Balai Arkeologi Ambon)

Gua ini dibentuk oleh aliran air yang agaknya merupakan perluasan dari sungai terdekat yang meluap. Lantai gua yang terdekat yang meluap. Lantai gua yang
berbatu ditutupi oleh lapisan sedimen yang membentuk parit dengan lebar sekitar dua meter. Pada kedua sisi parit ini tinggi sedimen mencapai sekitar satu meter.

Temuan permukaan didominasi oleh sebaran moluska yang menumpuk di bagian pintu masuk dan berasal dari jenis Gelonia sp; Terebralia sp.; Anadara sp. Terdapa juga beberapa fragmen gerabah dan fragmen keramik asing dari Cina. Fragmen tulang hewan juga dapat nampak. Temuan terpenting di situs ini diwakili oleh keberadaan himpunan goresan dalam berbagai motif pada dinding gua. Bentuk geometris, abstrak, manusia, organ tubuh (tangan dan kaki), pohon, manusia dan motif perahu ditampilkan pada dinding gua. Terlihat memang adanya distors dengan goresan-goresan yang lebih modern seperti bentuk alfabet, namun secara umum sebagian besar menunjukan karakter motif yang cukup tua.

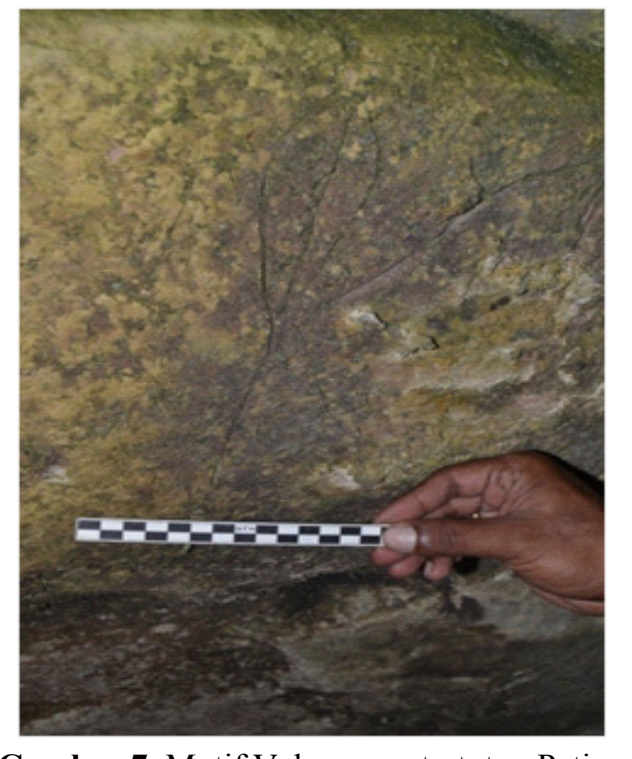

Gambar 7. Motif Vulva yang tertutup Patina (Sumber: Dokumen Balai Arkeologi Ambon)

Salah satu motif yang memiliki kenampakan cukup tua adalah motif vulva. Motif ini ditemukan di sisi timur dari pintu utara gua. Ditampilkan dengan goresan tipis namun dalam, motif ini sudah terlihat berusia lebih tua karena lapisan patina yang hampir menutupi lukisan ini. Panjang motif adalah $25 \mathrm{~cm}$ dan lebar $6 \mathrm{~cm}$. Motif kedua yang ditampilkan adalah konstruksi geometris dengan bentuk yang mirip dengan 'pohon kehidupan' sebagaimana ditemukan juga di situs Dudumahan, Kepulauan Kei dan pola hias nekara Dong Son. Motif ini memiliki panjang $30 \mathrm{~cm}$ dan lebar $15 \mathrm{~cm}$. Terdapa juga dua motif geometris berupa mata panah. Satu dalam posisi menghadap ke atas dan satu dalam posisi menghadap ke bawah. Dimens motif ini adalah memiliki panjang $10 \mathrm{~cm}$ dan lebar sekitar $4 \mathrm{~cm}$. Motif antromorfik juga ditampilkan dalam asosiasi dengan beberapa motif geometris lain. Motif yang paling menarik barangkali diwakili oleh keberadaan bentuk telapak kaki manusia. Satu moti diterakan secara sepasang dan satu motif ditampilkan hanya salah satu telapak kaki. Terdapat juga motif fauna yang diwakili oleh bentuk buaya atau cecak.

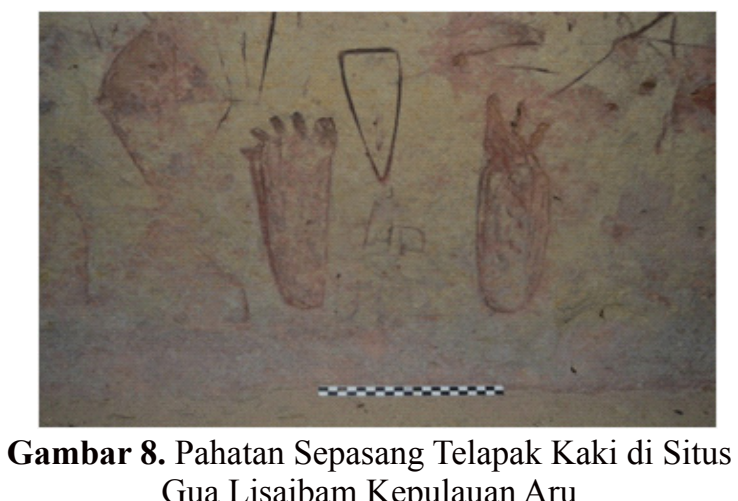

Gua Lisaibam Kepulauan Aru

(Sumber: Dokumen Balai Arkeologi Ambon)

Keberadaan aneka lukisan cadas di Gua Lisa Ibam ini memperluas geografi sebaran situs-situs lukisan cadas. Jika sebelumnya situs lukisan cadas di pulau-pulau selatan di Maluku hanya ditemukan di Kepulauan Kei, kini meluas ke timur hingga ke Aru. Mengamati karakter situs-situs lukisan cadas lain di Maluku, Lisa Ibam adalah satu-satunya situs dengan seluruh motif yang diterakan dengan teknik gores.

\section{Pembahasan}

Nilai penting Aru sebagai sebuah kawasan dalam kaitan dengan wilayah sekitarnya dan dunia luar setidaknya dapat ditinjau dari dua aspek. Pertama, terkait dengan kondisi paleogeografi bahwa Kepulauan Aru merupakan satu kesatuan landas kontinen dengan Papua dan Australia. Dalam konteks ini sejarah lingkungan Aru senantiasa melekat dengan daratan induknya di sebelah timur dan selatan. Kedua, keberadaan Aru sebagai salah satu kawasan sumber komoditi eksotik, membuat wilayah ini terhubung dengan pasar regional dan global. Implikasi atas kondisi khas ini adalah Aru berkembang sebagai wilayah terbuka melalui kontak dan interaksi serta berdampak langsung bagi keragaman demografi di wilayah ini pada masa lalu.

Melalui sudut pandang dalam aspek pertama, perubahan lingkungan regional yang terjadi secara gradual pada masa Plestosen Akhir, membawa implikasi besar bagi profil Paparan Sahul yang mencakup
Kepulauan Aru, Papua dan Australia. Naiknya muka air laut hingga mencapai ketinggian saat ini pada sekitar 11,500 tahun yang lalu, telah menenggelamkan kawasan luas dataran rendah di sekitar Kepulauan Aru, Papua dan Australia bagian utara yang kini menjadi Laut Arafura. Himpunan massa daratan yang membentuk Kepulauan Aru saat ini, merupakan wilayah dataran tinggi dalam kawasan setempat yang oleh karena itu menjadi semacam 'kapal penyelamat' bagi spesiesspesies yang berdiam di dalamnya. Sebagai wilayah perluasan Papua dan Australia Kepulauan baru ini tetap menampilkan profil ekologi yang mencerminkan daratan induk di seberang lautan. Karakter flora dan fauna Kepulauan Aru menjadi refleksi profil flor dan fauna yang ada di wilayah Papua dan Australia. Variasi-variasi yang bersifat loka muncul seiring berjalannya waktu, namun hakekat sebagai bagian Austrolo-Papua tetap nampak di wilayah ini. Hewan keci berkantung (marsupial); Kangguru, Kasuari dan Cendrawasih menjadi fauna ikonik yang membuktikan kedekatan ekologis tersebut.

Salah satu implikasi geografis ata perubahan lingkungan yang drastis ini adalah muncul selat-selat sempit dan panjang yang memisahkan satu daratan dengan daratan lainnya di Kepulauan Aru. Karakter geografis ini kemudian menjadi salah satu penanda lingkungan yang khas. Beberapa selat utama tersebut adalah Sungai Manumbai yang memisahkan Pulau Wokam dan Kobror; Sungai Wokai yang memisahkan pulau Kobror dan Maikoor; Sungai Maikor yang memisahkan pulau Maikor dan Trangan serta Sungai Sisir yang memisahkan pula Kola dan Wokam. Selain di kawasan pesisir sepanjang sungai-sungai inilah muncu dan berkembang pemukiman tradisional ke arah pedalaman. Sungai Manumbai adalah salah satu yang terkenal. Di sepanjang sungai Manumbai inilah, naturalis terkena Alfred Russel Wallace tinggal selama enam minggu untuk mengumpulkan spesies-spesies hewan sebagai dasar kajian ilmiahnya yang kemudian menjadi salah satu rujukan utama 
dalam studi evolusi dan biogeografi. Secara total ilmuwan dunia ini mengumpulkan lebih dari sembilan ribu spesimen objek-objek alam dari sekitar seribu enam ratus spesies (Wallace, 1857; O'Connor, 2005)

Hasil penelitian Wallace di Aru kemudian disatukan sebagai sebuah karya ilmiahbersamak wilayah lain di Asia Tenggara. Dalam buku berjudul The Malay Archipelago ini, Wallace mengemukakan teorinya, dengan mengac pada distribusi hewan dan burung, bahwa Kepulauan Aru pernah bergabung dengan Papua sebagai satu wilayah. Meski dalam tulisann mengenai turun-naiknya muka air laut sebagai penjelasan atas fenomena ini. Dalam catatannya Wallace juga menyebutkan tentang bagaimana ragam spesies ini berperan dalam ekonomi masyarakat Aru pada masa itu. Termasuk bagaimana hewan khas Australia Kangguru, masih umum ditemukan dan menjadi bagian dari konsumsi masyaraka setempat.

Kejelian pengamatan antropomorfik khas Wallace yang juga membuat dia mampu mengamati keragaman fisikal di antara para penduduk Kepulauan Aru. Meski merupakan wilayah yang memiliki kedekatan lingkungan wilayah yang memiliki kedekatan lingkungan
dengan Papua, penduduk asli Aru memiliki kenampakan fisik yang berbeda dengan penduduk asli Papua maupun Orang Aborigin di Australia. Fenomena ini direkam oleh Wallace dalam catatannya:

Many of the natives, though equally dark with the others, have little of the

Papuan physiognomy, but have mored

with more glossy curling hair. These at first

quite puzzled me, for they have

o more resemblance to Malay than to

Papuan, and the darkness of skin

and hair would forbid the idea of Dutch admixture. Listening to their

conversation, however, I detected some

cleared up the difficulty I at once

nderstood that some early $P C$ traders had penetrated to these islands, and mixed with the natives ...(O'Connor, 2005)

Catatan-catatan Wallace di atas terkait kondisi alam dan masyarakat di Kepulauan Aru memang telah menjadi salah satu sumber klasik. Ragam referensi yang lebih kini, sebagai hasil penelitian yang lebih kontemporer, memberikan kepada kita pengetahuan yang lebih jelas dan mendalam terkait karakter Kepulauan Aru sebagai sebuah wilayah. Karya akademis Spyer (2000) dan O'Connor et.al (2005) banyak memberikan koreksi dan meluaskan pandangan kita terhadap rekam perjalanan Wallace di wilayah ini. Lepas dari semua kondisi tersebut, buah karya Wallace dan beberapa ilmuwan lain yang sejaman menjadi dokumen penting bagi kontribusi terkait pengetahuan sejarah budaya masa lalu di Kepulauan Aru. Aspekaspek yang dibahas dibawah ini, sebagai tinjauan atas data yang dikumpulkan selama survey arkeologi di Pulau Kobror oleh Balai Arkeologi Ambon pada tahun 2011, juga dikemukakan dengan mengacu pada himpunan karya akademis atas Kepulauan Aru yang telah diterbitkan.

a. Seni Cadas di Lisa Ibam: Lingkungan Gua dan Tradisi Prasejarah

Kawasan Wallacea dan sekitarnya dikenal sebagai wilayah yang kaya denga situs-situs seni cadas. Ragam bentuk sen khas ini tersebar mulai dari Sulawesi hingga Maluku. Bahkan jika bergerak lebih ke selatan, ratusan situs seni cadas ditemukan juga di wilayah tetangga yaitu Papua dan Australia. Di Australia, salah satu wilayah yang terkenal dengan sebaran situs lukisan cadas adalah himpunan gua-gua di Kimberly Region, Australia Barat. Model seni serupa juga ditemukan secara luas di wilayah Papua Situs-situs ini umumnya tersebar di daerah Kokas, Kaimana, Sentani hingga Jayawijaya

Di dalam kawasan Wallacea, jejak aktivitas seni cadas masa lalu dapat ditemukan dibeberapa situs utama di Sulawesi, umumnya di Sulawesi Bagian Selatan dan sekitarnya.
Di sini situs lukisan cadas teridentifikasi di Kawasan Maros dan Kawasan Pangkajene. Pada kawasan kedua ini terdapat sebaran situs yang luas antara lain Garunggung, Lasitae, Bulu Ballang, Lompoa, Kassi, Sapiria, Sakapao, Akarasaka, Sumpangbita, Bulusumi, Bulu Sipong, Camingkana, Patenungan, Bulu Ribba, Salluka, dan Cumi Lantang. Selain di dua kompleks besar ini, situs lukisan cadas juga ditemukan di Pulau Muna. Motif-motif bertema maritim dalam bentuk perahu ditemukan pada lukisan cadas di situs Lene Hara, Timor-Timur (O'Connor, et.al, 2002).

Di Kepulauan Maluku situs seni cadas ditemukan setidaknya di empat titik di pulau berbeda. Mulai dari Pulau Buru hingga Kepulauan Kei. Rekam perdana atas situs lukisan cadas disampaikan oleh J. Roder yang ketika itu melakukan survei sebagai bagian dari ekspedisi Fronebius tahun 1937 (Ririmasse, 2005). Dalam catatannya Roder menyebutkan mengenai keberadaan lukisan cadas di aliran sungai Tala dan teluk Saleman. Dalam lingkup situs ini ditemukan motif geometris yang diterakan dalam asosiasi dengan motif zoomorfik dan antromorfik. Teknik yang digunakan berupa stensil, poles hingga gores. Lukisan cadas yang ditemukan di Teluk Saleman, diterakan dengan variasi warna berupa merah, putih dan hitam. Situs lukisan cadas di Wamkana, pesisir selatan Pulau Buru didata oleh tim Balai Arkeologi Ambon pada tahun 1997 (Ririmasse, 2005). Di situs ini ditemukan lukisan dengan motif geometris dan antromorfik yang diterakan pada dinding cadas di kawasan pesisir. Kehadiran situs Wamkana mewakili sisi paling barat sebaran situs lukisan cadas di Kepulauan Maluku. Situs seni cadas di Maluku yang paling kompleks sejauh ini diwakili oleh situs Dudumahan di Ohoidertawun, Kepulauan Kei. Di situs ini terdapat lebih dari 200 motif lukisan yang diterakan dalam aneka warna (Ririmasse, 2005). Motif yang ditampilkan meliputi motif geometris, motif manusia, perahu dan benda-benda alam. Ballard (1988), dalam tinjauannya mengenai situs ini menyebutkan bahwa situs ini diperkirakan ersebaran penutur bahasa Austronesia mencapai wilayah Tenggara Kepulauan Maluku (Ballard, 1988).

Identifikasi atas Gua Lisa Ibam telah memperkaya himpunan situs seni cadas yan terdapat di Kepulauan Maluku. Dengan lebih dari duapuluh motif, Lisa Ibam merupakan situs seni cadas dengan teknik gores yang paling kaya di Kepulauan ini. Situs dengan teknik serupa dalam kawasan ditemukan oleh Roder di Aliran Sungai Tala dengan moti yang ditampilkan adalah geometris.

Mengamati motif-motif yang diterakan di Lisa Ibam beberapa eksplanasi awal dapat dikemukakan. Motif Vulva adalah motif khas yang merupakan representasi simbo genetalia. Kehadiran vulva sebagai simbol secara luas dikenal di Asia Tenggara dan belahan lain di dunia. Kehadiran motif in umumnya dikaitkan dengan simbol kesuburan dan kelahiran kembali. Di Kepulauan Maluku Tenggara sendiri, model representasi simbolsimbol reproduksi cukup umum dikenal. Kehadiran elemen-elemen simbolik yang mewakili figur fungsi reproduksi laki-laki dan perempuan senantiasa hadir bersamaan dan mencerminkan prasyarat suatu bentuk penciptaan kehidupan baru (De Jonge dan van Dijk, 1995; Ririmasse, 2011a). Motif pohon yang diterakan pada sisi pintu gua menunjukan bentuk yang selaras dengan motif pohon yang digunakan pada pola hias nekara Dong-Son dan juga umum ditemukan pada berbagai produk tenun tradisional di Nusantara. Demikian halnya dengan motif bintang yang ditampilkan dengan garis-garis adiasi di sekelilingnya. Model representasi benda-benda langit ini cukup dikenal di beberapa situs lukisan cadas di Kepulauan Asia Tenggara. Di situs Dudumahan, Kepulauan Kei, motif serupa ditampilkan dalam asosiasi dengan motif matahari. Kehadiran motif perahu barangkali menjadi bentuk yang paling menarik. Utamanya menimbang luasnya aplikasi tema perahu sebagai simbol di Kepulauan Maluku Tenggara. Motif 
perahu dalam berbagai variasinya juga diidentifikasi di situs Dudumahan Kepulauan Kei. Penggunaan tema perahu sebaga simbol dalam lingkup Kepulauan Maluku Tenggara kiranya mencakup aspek yang kompleks. Perahu diadopsi sebagai sumbe untuk ragam nilai filosofis untuk religi, sistem struktur sosial, kosmologi, hingga representasi material atas nilai-nilai simbolik itu sendiri. Bukan kebetulan kiranya jika dalam penelitian ini, juga teridentifikasi, bangkai perahu arwah di situs Sila Bata-Bat yang digunakan sebagai wadah simbolik bagi si mati di Kepulauan Aru.

Terkait kapan goresan-goresan in diterakan, kiranya masih memerlukan pengamatan lebih jauh. Model komparasi morfologi motif dengan situs-situs sen cadas lain dalam kawasan dapat menjadi opsi untuk memperkirakan kronologi situs ini. Selain tentunya upaya untuk menemukan penanggalan absolute melalui ekskavasi. Aspek terpenting yang perlu ditindaklanjut memang adalah upaya menemukan profil budaya dalam konteks arkeologis di situs ini. Saat melakukan survei tim masih terkendala perijinan dari pemilik lahan, yaitu piha keluarga yang masih memandang situs sebagai pusaka keluarga yang dikeramatkan. Dengan alasan tersebut, meski upaya negosiasi telah dilakukan, tim tidak mendapat ijin untuk melakukan ekskavasi di Gua Lisa Ibam.

b. Woma di Sila Bata-Bata: Religi dan Ekonomi dalam Tradisi

Saat pertama kali mengamati kerama di Desa Sila Bata-Bata hampir tidak ad kesan khusus di sana. Sekilas profil struktur yang sederhana dengan gaya bangunan yang kelihatan sangat baru, membuat nila 'kuno' dari objek ini seakan lenyap. Ukura struktur yang relatif kecil membuat objek ini tenggelam di antara himpunan rumah penduduk. Keletakannya yang berada setelah dermaga, tidak memberi kesan peran penting objek ini dalam ruang desa. Dalam kenyataannya, objek ini adalah penanda

utama pusat religi tradisional pemukiman di masa lalu. Bagian dari tradisi yang sudah berjalan lintas generasi dalam kawasan ini.

Model keramat seperti yang ditemukan di Sila Bata-Bata ini memang umum ditemukan di Kepulauan Maluku Tenggara (Ririmasse, 2007). Di Kepulauan Kei, objek dengan karakter khas seperti in biasanya disebut sebagai Woma. Bentuk Woma biasanya diwakili oleh struktur yang dibentuk oleh batu bersusun atau dolmen. Di sekitar woma biasanya diletakan anek artefak mulai dari keramik hingga meriam. Di Kepulauan Tanimbar, khususnya di Pulau Yamdena, istilah yang digunakan keramat sejenis adalah natar. Bentuk paling terkenal dari natar adalah struktur berupa monumenmonumen tradisional yang direkayasa menyerupai bentuk sebuah perahu artifisial. Meski memiliki istilah dan morfologi yang berbeda-beda, namun sejatinya tujuan keramat antara satu wilayah dengan wilayah lainnya dalam kepulauan ini memiliki benang merah. Yaitu sebagai representasi material atas ikatan sosial bagi komunitas.

Di Kepulauan Aru keramat seperti ini disebut sebagai momosin. Istilah yang berasosiasi dengan sebutan untuk para yar yang diyakini berasal dari hewan. Momosin kiranya dapat dipandang setara dengan istilah Pamali yang umum digunakan dalam bahasa melayu pasar di Maluku. Biasanya bangunan kecil ini difungsikan sebagai pusa ritual desa. Dimana secara spasial menanda tempat kehadiran leluhur dalam pemukiman Penduduk biasanya meletakan aneka sesaj dan persembahan di tempat ini. Dulu, umumnya persembahan diletakan sebelum penduduk mulai menyelam pada saat musim mencari mutiara. Demikian halnya dengan mereka yang akan melakukan pelayaran. Dengan memberikan sesaji, para penyelam dan mereka yang berlayar mengharapkan mendapat perlindungan dan keselamatan dar para leluhur. Bendera putih yang dipajang di sisi keramat, biasanya juga disematkan di perahu pada saat pelayaran. Kehadiran leluhur, juga dipandang mampu memberikan nasib baik sehingga hasil yang dicapai oleh para penyelam juga berlimpah.

c. Penguburan Terbuka: Antara Fakta Sejarah dan Tradisi

Data etnohistori dari sumber-sumber kolonial menyebutkan mengenai eksistensi tradisi ini di Kepulauan Maluku Tenggara. Catatan terkait fenomena spesifik ini direkam oleh Drabbe, seorang rohaniwan katolik yang bertugas di Kepulauan Tanimbar, pada paruh pertama abadke-20. Dalam catatannya Drabbe menjelaskan mengenai tradisi penguburan khas penduduk Tanimbar. Dalam tradisi masyarakat ini di masa lalu, jasad si mati biasanya akan diletakannya di alam terbuka di atas balai-balai hingga mengering. Setelah itu, bagian tengkorak (cranium) dan tulang leher akan diletakan di tempat-tempat tertentu. Sementara bagian kerangka lainnya akan dikuburkan. Tempat yang biasanya digunakan untuk menyimpan tengkorak dan tulang leher si mati adalah di pusat ritual perkampungan atau di altar keluarga di dalam rumah yang disebut sebagai tafu. Tahun 2006 saat tim Balai Arkeologi Ambon melakukan survei ke salah satu situs bekas pemukiman kuna di Tanimbar, jejak fenomena khas ini masih terlihat. Dimana pada relung-relung dinding cadas yang disekitar pemukiman, diletakan tengkorak leluhur yang telah meninggal.

Praktek penguburan dengan meletakan si mati di alam terbuka juga ditemukan di Kepulauan Kei. Di sini, jenasah diletakan di dalam relung-relung dinding cadas dan gua sebagaimana ditemukan di situs Dudumahan, di Desa Ohoidertawun. Himpunan kerangka dan fragmen tengkorak ditemukan bersama dengan fragmen gerabah, logam dan keramik asing yang agaknya digunakan sebagai bekal kubur. Tidak ditemukan indikasi pencuplikan bagian-bagian tubuh tertentu dari jasad si mati sebagaimana yang ditemukan di Kepulauan Tanimbar. Praktek penguburan ini berasosiasi dalam satu lingkungan situs dengan sebaran lebih dari dua ratus motif lukisan cadas yang diterakan sepanjang dinding cadas di bibir pantai.

Hasil pengamatan di situs penguburan desa Sila Bata-Bata menunjukan fenomen serupa. Jasad si mati diletakan di atas lantai dinding gamping bersama dengan aneka beka kubur. Himpunan tengkorak dan kerangka orang dewasa dan anak-anak ditemukan bersama dengan bekal kubur mulai dari gerabah lokal, keramik asing, artefak logam, manik-manik, koin mata uang asing, Terdapa juga beberapa gelang kerang. Temuan yang paling penting agaknya diwakili oleh keberadaan fragmen bangkai perahu yang agaknya digunakan sebagai perahu arwah (boat coffin) bagi si mati. Informasi yang diberikan oleh penduduk menyebutkan bahwa dahulu, lebih banyak lagi bangkai perahu arwah serupa yang terdapat di situs ini.

Model penguburan dengan menggunakan wadah perahu kiranya buka merupakan halasing dalam profil sejarah budaya di Kepulauan Asia Tenggara. Di Situs-situs arkeologi di Asia Tenggara Daratan seperti di Vietnam, telah ditemukan penguburan dengan menggunakan wada perahu. Fenomena serupa juga ditemukand Vietnam (Bellwood et.al, 2006). Data Etnohistori juga mneyebutkan mengenai fenomena serupa di kepulauan Maluku Tenggara sebagai ditemukan di Kepulauan Tanimbar. Meski demikian rekam stud arkeologis yang dilakukan oleh Balai Arkeologi Ambon belum pernah menemukan adanya jasad perahu yang dimanfaatkan sebagai wahana penguburan. Temuan $d$ Sila Bata-bata adalah temuan jasad perahu pertama yang ditemukan oleh Balai Arkeolog Ambon di Kepulauan Maluku.

Aplikasi perahu sebagai wahana penguburan bagi individu yang meningga kiranya terkait erat dengan hakekat perahu sebagai simbol dalam struktur budaya masyarakat di Kepulauan Asia Tenggara (Ririmasse, 2008, 2010b; 2011b). Fenomena ini ditemukan secara luas dalam rekan sejarah budaya kawasan ini. Bahkan hingga saat ini aplikasi perahu sebagai simbol merupakan bagian yang masih lestari dalam 
profil budaya berbagai komunitas tradisiona di Asia Tenggara. Perahu dipandang memiliki nilai filosofis yang kemudian diadopsi sebaga inspirasi bagi kosmologi tradisional. Perahu dan tata pelayarannya juga diadopsi sebaga sumber bagi model struktur sosial tradisional. Dimana peran para pemimpin adat direka sedemikian rupa sehingga dipandang setara dengan peran-peran spesifik pada sebuah perahu.

Nilai religi melekat dengan ragam kepercayaan yang mengaitkan perahu sebagai wahana menuju dunia orang mati. Umum dikenal pada masyarakat kepulauan di Asia Tenggara bahwa dunia sesudah mati terletak di seberang kaki langit. Di pulau jauh yang melewati batas-batas transedental. Perahu kemudian digunakan sebagai wahana untuk mengantar si mati menuju dunia baru dan tempat peristirahatannya yang terakhir.

Sebagai masyarakat yang mendiami wilayah kepulauan, penduduk Aru juga akrab dengan tema-tema perahu sebagai simbol. Perahu tidak hanya dipandang semat sebagai wahana bagi si mati dalam aktivitas penguburan. Namun perahu juga, sebagaimana ditemukan di wilayah lain, digunakan sebagai sumber bagi konstruksi sistem tata-sosia Masyarakat tradisional di Kepulauan Aru umumnya juga mengenal model tata-sosia yang mengacu pada perahu sebagai simbol. Masyarakat dan pemukimannya dipandang sebagai sebuah perahu dengan segala kompleksitasnya. Para tetua adat dianggap memiliki peran yang serupa dengan fungsifungsi spesifik di sebuah perahu. Anggota keluarga dan masyarakat lain merupakan para penumpang. Kehidupan bersama sebaga sebuah komunitas, dipandang setara dengan pelayaran sebuah perahu,dimana keberhasilan mencapai tujuan bergantung pada harmonisasi ragam fungsi di dalam sebuah perahu.

Eksistensi penguburan terbuka dan bangkai perahu arwah ini kiranya layak untuk kelak ditinjau lebih jauh. Identifikasi atas situ sejenis dapat dilakukan dengan meluaskan survey dan pengamatan lebih ke selatan da timur Kepulauan Aru. Rekam atas situs-situs khas ini dapat memberi gambaran yang lebih tradisional di wilayah ini. Demikian halnya upaya untuk menemukan jejak material lain perahu arwah, akan mempertegas eksplanasi aplikasi perahu sebagai simbol dalam konsturksi sejarah budaya Kepulauan Maluku Tenggara. Pemahaman atas kedua fenomena khas ini akan memberi pengetahuan yang lebih mendalam terkait dinamika sosial masa lalu di Kepulauan Aru.

\section{PENUTUP}

Kepulauan Aru merupakan salah satu kawasan penting dalam studiarkeologi di Maluku. Geografi Kepulauan Aru yang berada pada kawasan tapal batas Asia-Australia memberi nilai penting bagi studi sejarah budaya di kawasan ini. Fakta paleogeografi sebagai bagian dari perluasan Papua-Australia di masa lalu, sebagaimana dicirikan dengan kedekatan profil flora dan fauna, merupakan indikator utama bagi potensi Aru dalam studi arkeologi kawasan.

Pulau Kobror merupakan salah satu pulau utama dalam gugus Kepulauan Aru. Pulau ini juga pernah menjadi lokus penelitian bagi naturalis legendaris Alfred Russel Wallace. Rekam penelitian Wallace seabad silam, bersama beberapa hasil penelitian yang lebih kini, menjadi dasar bagi Balai Arkeologi Ambon untuk melakukan survei awal, mengamati potensi arkeologis dan sejarah budaya di wilayah ini.

Penelitian kali ini berhasil mengidentifikasi beberapa situs yang mewakili gambar besar sejarah budaya di Pulau Kobror dan Kepulauan Aru meliputi: Situs Lukisan Cadas di Gua Lisa Ibam dan Situs Penguburan Terbuka di Sila BataBata. Di Lisa Ibam, teridentifikasi lebih dari tigapuluh motif lukisan cadas, yang diterakan dengan teknik gores. Motif yang ditampilkan bervariasi antara lain motif geometrik, vulva, bintang, antromorfik dan bagian tubuh hingga zoomorfik. Hasi pengamatan menunjukan Lisa Ibam potensia untuk ditinjau lebih jauh, dengan rekam data yang lebih detail dan ekskavasi untuk rekam kronologis. Penguburan terbuka di Sila Bata-Bata mencerminkan praktekpraktek tradisi setempat yang mewakili kompleksitas dinamika sosial masa lalu di Kepulauan Aru. Salah satu aspek yang terekam adalah eksistensi bangkai perahu arwah yang digunakan sebagai wahana bagi mereka yang mati. Keberadaan fenomena ini mempertegas aplikasi tema perahu sebagai simbol yang umum dikenal di Kepulauan Maluku Tenggara.

Hasil penelitian ini merupakan cermin bahwa wilayah pedalaman Kobror dan pulau-pulau lain di selatan Aru layak untuk ditinjau lebih jauh dalam studi arkeologis. Rekam data arkeologis di Kobror kiranya baru merupakan sebagian kecil gambar dari profil kompleks sejarah budaya di Kepulauan Aru. Pengamatan ke depan dapat difokuskan pada wilayah-wilayah pemukiman tradisional terutama kawasan yang terletak di sepanjang selat-selat kecil yang membelah kepulauan Aru beserta segenap potensi sejarah budaya di dalamnya.

\section{$* * * * *$}

\section{DAFTAR PUSTAKA}

Andaya, L. 1993a. Centers and peripheries in Maluku. Cakalele: Maluku Studies Research Journal 4:1-21.

Andaya, L. 1993b. The World of Maluku: Eastern

Indonesia in the Early Modern Period.
Honolulu: University of Hawai'I Press.

van Balgooy, M.M.J. 1996. Vegetation sketch of The Aru Islands. In H.P. Nooteboom (ed.), People and Conservation . pp. 1-14. Amsterdam: Nederlandse Commissie Voor InternationaleNatuurbescherming. Mededelingan 30

Ballard, C. 1988. Dudumahan: a rock art site on Kai Kecil, southeast Moluccas. Bulletin of the Indo-Pacific PrehistoryAssociation 8:139-61.
Bellwood, P. 1997. Prehistory of the IndoMalaysian Archipelago. 2nd Edition.

De Jonge, N and van Dijk, T. 1995. Forgotten Islands of Indonesia: The Art and Culture Periplus.

Healey, C. 1995. Traps and trapping in the Aru Islands. Cakalele: Maluku Research Journal 6:51-65.

Hidayat, H. 1998. Forest management by the local peoples in Aru District, southea Maluku, in A Step Toward Forest Conservation Strategy(1) - Interim Roport. Unpublished report to IGES www.iges.or.jp/en/fc/phase1/ir98-3-9. PDF

O'Connor, S., M. Spriggs, and P. Veth. 2002. Excavation at Lene Hara cave establishes to 35,000 years ago. Antiquity 76:45-50

O'Connor, S., M. Spriggs, and P. Veth. 2005. The Archaeology of the Aru Islands, Easter University.

Ririmasse, M. 2005. Jejak dan Prospek Penelitian Arkeologi di Maluku. Dalam Kapata Arkeologi Ambon. pp. 35-55

Ririmasse, M. 2007. Ruang Sebagai Wahana Makna: Aspek Simbolik dalam Rekayas Kapata Arkeologi Vol. 3 No 6 . Ambon: Balai Arkeologi Ambon pp. 84.110

Ririmasse, M. 2008. Visualisasi tema perahu dalam rekayasa situs arkeologi di Maluku. Dalam Naditira Widya Volume 2 No. . Banjarmasin: Balai Arkeologi Banjarmasin. pp. 142-157

Ririmasse, M. 2010a. Arkeologi Pulau-Pulau Terdepan di Maluku: Sebuah Tinjauan No. 10. Ambon: Balai Arkeologi Ambon. pp. $71-89$

Ririmasse, M. 2010b. Boat Symbolism an Identity in the Insular Southeast Asia: A Case Study from the Southeast Moluccas. M.A Thesis. Leiden. Rijkuniversite Leiden. Unpublished 
Ririmasse, M. 2011a. Arkeologi Kawasan Tapal Batas: Koneksitas Kepulauan Maluku dan Papua. Papua Vol. 3 No.1 Jayapura: Balai Arkeologi Jayapura. pp. 23-38.

Ririmasse, M. 2011b. Laut untuk Semua. Makalah disampaikan dalam Evaluasi Hasil Penelitian Arkeologi 2011,Banjarmasin.

Spriggs, M., P. Veth, and S. O'Connor. 1998. In the footsteps of Wallace: the first two seasons of archaeological research in the Aru Islands, Maluku. Cakalele: Maluku Studies Research Journal9(2):63-80.

Spyer, P. 2000. The Memory of Trade: Modernity's Entanglements on an Eastern Indonesian Island.Durham and London:Duke University Press.

Swadling, P. 1996. Plumes From Paradise: Trade Cycles in Outer Southeast Asia and Their Impact on New Guinea and Nearby Islands Until 1920.Port Moresby: Papua New Guinean National Museum in association with RobertBrown and Associates (Queensland).

Wallace, A.R. 1857. On the natural history of the Aru Islands. Annals and Magazine of Natural History(Series 2) 20:473-85. InternationaleNatuurbescherming. Mededelingan 30. 